\title{
HIV ile Yaşayan Bireylerde Tetanos Aşısının Rapeli Daha Erken Yapılmalı Mı?
}

\section{Should Tetanus Vaccine Booster be Given Earlier in Individuals Living with HIV?}

\author{
Arzu NAZLI ${ }^{1}(I D)$, Buse KENANOĞLU²(ID), Meltem IŞIKGÖZ TAŞBAKAN²(ID), \\ Hüsnü PULLUKÇU²(ID), Ayşin ZEYTiNOĞLU³(ID), Deniz GÖKENGIN²(ID) \\ ${ }^{1}$ Dokuz Eylül Üniversitesi Tıp Fakültesi, Enfeksiyon Hastalıkları ve Klinik Mikrobiyoloji Anabilim Dalı, İzmir. \\ ${ }^{1}$ Dokuz Eylül University Faculty of Medicine, Department of Infectious Diseases and Clinical Microbiology, Izmir, Turkey. \\ ${ }^{2}$ Ege Üniversitesi Tıp Fakültesi, Enfeksiyon Hastalıkları ve Klinik Mikrobiyoloji Anabilim Dalı, İzmir. \\ 2 Ege University Faculty of Medicine, Department of Infectious Diseases and Clinical Microbiology, Izmir, Turkey. \\ ${ }^{3}$ Ege Üniversitesi Tıp Fakültesi, Tıbbi Mikrobiyoloji Anabilim Dalı, İzmir. \\ 3 Ege University Faculty of Medicine, Department of Medical Microbiology, Izmir, Turkey.
}

Makale Atıfı: Nazlı A, Kenanoğlu B, Işıkgöz Taşbakan M, Pullukçu H, Zeytinoğlu A, Gökengin D. HIV ile yaşayan bireylerde tetanos aşısının rapeli daha erken yapılmalı mı? Mikrobiyol Bul 2022;56(1):49-58.

\section{ÖZ}

Tetanos insidansı, aşısının bulunması ile ciddi oranda azalmıştır. Koruyucu antikor düzeylerinin sağlanması için rutin aşı şemasından sonra her 10 yılda bir rapel doz gereklidir. İnsan bağışıkık yetmezliği virüsü (HIV) ile yaşayan bireylerde tetanos rapel dozları için öneriler, genel toplumdaki ile aynıdır. Ancak HIV ile yaşayan bireylerde tetanos antikorlarının ne kadar süreyle koruyucu düzeyde kaldığı bilinmemektedir. Çalışmamızda HIV ile enfekte bireylerin tetanos aşısına verdiği yanıta etki eden faktörlerin belirlenmesi ve tetanos antitoksin düzeyinin rapel dozun yapılma zamanını belirlemedeki rolünün değerlendirilmesi amaçlanmıştır. Ege Üniversitesi Tıp Fakültesi Enfeksiyon Hastalıkları ve Klinik Mikrobiyoloji Anabilim Dalına bağlı Erişkin Aşı Polikliniğine 30 Ekim - 30 Kasım 2020 tarihleri arasında başvuran HIV ile yaşayan bireylerde tetanos antikorları araştırılmıştır. Hastaların demografik verileri ve primer tetanos aşılanma öyküleri ve rapel doz zamanları poliklinik defterlerinden elde edilmiştir. Tetanoz antikorları Clostridium tetani toxin $5 \mathrm{~S}$ IgG-"enzyme linked immunosorbent assay (ELISA)" kiti (NovaLisa, Novatec Immundiagnostica, Almanya) ile 'enzim immunoassay" (EIA) yöntemiyle saptanmıştır. Elde edilen antikor titreleri, < $0.01 \mathrm{lU} / \mathrm{ml}$ negatif, $0.01-0.5 \mathrm{IU} / \mathrm{ml}$ arası zayıf pozitif, $0.51-1.0 \mathrm{IU} / \mathrm{ml}$ arası pozitif ve $>1.1 \mathrm{IU} / \mathrm{ml}$ kuvvetli pozitif olarak değerlendirilmiştir. $\geq 0.50 \mathrm{IU} / \mathrm{ml}$ üzeri titreler koruyucu olarak kabul edilmiştir. Çalışmaya 146 [erkek $(n=126)$ ve kadın $(n=40)$ ] HIV ile yaşayan birey dahil edilmiştir. Yaş ortalaması $39.5 \pm 11.20$ yıldır (yaş aralığı: 1865). Katılımcıların 114 (\%78.1)'ünde tetanos için koruyucu antikor düzeyi saptanmıştır. Koruyucu antikor seviyesi oluşması için en ideal CD4+ T lenfositi sayısı, "receiver operating characteristics (ROC)" analizi ile $\geq 218$ hücre $/ \mathrm{mm}^{3}$ olarak belirlenmiştir. Çok değişkenli analizde, $<50$ yaş ( $\left.\mathrm{OR}=16.4, \% 95 \mathrm{GA}=4.9-55.2\right)$, tanı anında "acquired immune deficiency syndrome (AIDS)" bulunmaması (OR= 6.7, \%95 GA=1.0517.4) ve aşı anında $C D 4+T$ lenfositi sayısının $\geq 218$ hücre $/ \mathrm{mm}^{3}$ olmasının $(O R=4.2, \% 95 G A=1.05-17.4)$ koruyucu antikor seviyesi ile ilişkili olduğu saptanmıştır. HIV ile yaşayan bireylerde, genel topluma göre daha düşük düzeyde koruyucu tetanos antikorları bulunmaktadır. Özellikle $>50$ yaş, rapel doz sırasında 
CD4+ T lenfositi sayısı < 200 hücre/ $\mathrm{mm}^{3}$ olan ve başlangıçta AIDS kliniği ile başvuran HIV ile yaşayan bireylerde, rapel dozun daha erken gerekebileceği göz önünde bulundurulmalıdır.

Anahtar kelimeler: HIV; tetanos; aşl; antikor.

\section{ABSTRACT}

The incidence rate of tetanus has dramatically decreased following the discovery of the tetanus vaccine. A decennial booster dose is necessary to maintain the protective antibody levels after the primary vaccination schedule. The recommendations for the tetanus booster doses in adult "people living with acquired immune deficiency virus (HIV)" (PLWH) is similar to those for the general population. However, the duration of protective antibodies in PLWH is unknown. The aim of this study was to determine the factors affecting the response of HIV-infected individuals to tetanus vaccine and to evaluate the role of tetanus antitoxin level in determining the timing of the booster dose. PLWH attending the Adult Vaccination Unit of Ege University Faculty of Medicine Infectious Diseases and Clinical Microbiology Department were tested for tetanus antibodies from 30 October to 30 November 2020. Demographic information and the history of primary vaccination and booster doses were derived from medical files. Tetanus antibodies were detected with "enzyme immunoassay (EIA)" method with Clostridium tetani toxin 5S IgG-"enzyme linked immunosorbent assay (ELISA)" kit (Nova Lisa, Novatec Immundiagnostica, Germany). Antibody levels $<0.01 \mathrm{IU} / \mathrm{ml}$ were considered negative, $0.01-0.5 \mathrm{IU} / \mathrm{ml}$ weak positive, $0.51-1.0 \mathrm{IU} / \mathrm{ml}$ positive and $>1.1 \mathrm{IU} / \mathrm{ml}$ strong positive. A level $\geq 0.50 \mathrm{IU} / \mathrm{ml}$ was considered as protective. The study included 146 PLWH [men $(n=126)$ and women $(n=40)$ ]. The mean age was $39.5 \pm 11.20$ years (range: $18-65)$. Protective antibody level was detected in 114 (78.1\%) participants. Receiver operating characteristics (ROC) analysis revealed that the ideal lower limit of CD4+ T cell count during booster vaccination for a person to develop protective antibody level was calculated as $\geq 218 \mathrm{cell} / \mathrm{mm}^{3}$. In the multivariate analysis, it was found that age $<50$ years $(\mathrm{OR}=16.4,95 \% \mathrm{Cl}=4.9-55.2)$, the absence of AIDS at the time of diagnosis $(\mathrm{OR}=6.7,95 \% \mathrm{Cl}=1.05-17.4)$ and $\mathrm{CD} 4+\mathrm{T}$ cell count $\geq 218 \mathrm{cells} / \mathrm{mm}^{3}$ at the time of vaccination $(\mathrm{OR}=$ $4.2,95 \% \mathrm{Cl}=1.05-17.4$ ) were associated with protective levels of antibody. Protective levels of tetanus antibodies in PLWH are lower than the general population. It should be considered that the booster dose may be required earlier, especially in PLWH who are $>50$ years old, with CD4+ T lymphocyte count $<200$ cells $/ \mathrm{mm}^{3}$ during previous booster vaccination and who had AIDS at the time of the diagnosis.

Keywords: HIV; tetanus; vaccine; antibody.

\section{Giriş̧}

Tetanos, Clostridium tetani toksini tetanospazminin neden olduğu kontrol edilemeyen, ağrılı kas spazmları ile seyreden ve yaşamı tehdit eden bir hastalıktır.

Tetanos aşısı, ülkemizde 1968 yılından bu yana aşılama programı içinde yer almaktadır. Yaygın aşılama sayesinde tetanos insidansı on yıllar içinde önemli ölçüde azalmıştır ${ }^{1}$. Yapılan çalışmalarda, çocukluk çağındaki rutin aşılama şemasının ardından tetanos antitoksininin yüksek titrelere ulaştığı fakat yıllar içinde, özellikle de 50 yaşın üzerindeki bireylerde koruyucu seviyenin altına indiği gösterilmiştir ${ }^{2-6}$. Erişkin bağışıklama kapsamında, 15-49 yaş arasındaki kadınlar, gebeler ve askerler başta olmak üzere tüm erişkinlere tetanos aşısı önerilmektedir ${ }^{7-9}$. Daha önce aşılanmamış bireylerde rutin aşılama şeması, 0,1 ve 7. aylarda üç doz olacak şekilde uygulanmakta, primer aşılama şemasını tamamlayan erişkinlere ise 10 yılda bir rapel doz önerilmektedir ${ }^{7-9}$.

Insan bağışıklık yetmezliği virüsü (HIV) ile enfekte bireylerde, CD4+ T lenfositi yanıtının, antijen sunan hücre fonksiyonlarının ve sıvısal bağışık yanıt mekanizmalarının bozulması nedeniyle birçok enfeksiyon daha ciddi seyredebilmektedir. Bu nedenle bağışıklama bu grupta son derece önemlidir. HIV ile enfekte bireylerde tetanos bağışıklama endikas- 
yonları genel toplumdaki ile aynıdır ve CD4+ T lenfositi sayısından bağımsızdır. Yine de bağışıklık sistemindeki geri dönüşümsüz işlev bozuklukları nedeniyle aşıya verilen yanıt yeterli düzeyde olmayabilir ${ }^{10-13}$. Bu olgularda, tetanos antitoksininin ne kadar süreyle koruyucu düzeyde kaldığı tam olarak bilinmemektedir.

Çalışmamızda HIV ile enfekte bireylerin tetanos aşısına verdiği yanıta etki eden faktörlerin belirlenmesi ve tetanos antitoksin düzeyinin, rapel dozun yapılma zamanını belirlemedeki rolünün değerlendirilmesi amaçlanmıştır.

\section{GEREÇ ve YÖNTEM}

Bu çalışma Ege Üniversitesi Rektörlüğü Tıp Fakültesi Dekanlığı Tıbbi Araştırmalar Etik Kurulu onayı ile gerçekleştirildi (Karar No: 21-1.IT/67 ve Tarih: 29.01.2021).

Etik Kurul başvurusu yapıldıktan sonra Ege Üniversitesi Tıp Fakültesi Enfeksiyon Hastalıkları ve Klinik Mikrobiyoloji Anabilim Dalına bağlı Erişkin Aşı Polikliniğine 30 Ekim 2020 ve 30 Kasım 2020 tarihleri arasında başvuran ve çalışmaya katılmayı kabul eden 146 HIV ile yaşayan bireye tetanos antikor testi yapıldı. Pandemi dönemi olması nedeniyle bürokratik işlemlerin uzamasından dolayı etik kurul onayı çalışmaya başlandıktan sonra alındı. Hastaların demografik verileri ve tetanos aşılanma öyküleri poliklinik defterlerinden ve aşı kartlarından geriye dönük olarak elde edildi.

Tetanos antitoksini Clostridium tetani toxin 5S IgG--"enzyme linked immunosorbent assay (ELISA)" kiti (NovaLisa, Novatech Immundiagnostica, Almanya) ile "enzyme immunoassay' (EIA) yöntemiyle çalışıldı. Kit üreticinin önerisine göre testte elde edilen antikor titreleri $<0.01 \mathrm{IU} / \mathrm{ml}$ negatif, $0.01-0.5 \mathrm{IU} / \mathrm{ml}$ arası zayıf pozitif, $0.51-1.0 \mathrm{IU} / \mathrm{ml}$ arası pozitif ve > $1.1 \mathrm{IU} / \mathrm{ml}$ kuvvetli pozitif olarak rapor edildi. Çalışmamızda $\geq 0.50 \mathrm{IU} / \mathrm{ml}$, yeterli koruyucu antikor düzeyi olarak kabul edildi.

\section{İstatistiksel Analiz}

Tanımlayıcı veriler sayı ve yüzdelerle sunuldu. İstatistiksel anlamlılık düzeyi olarak $\mathrm{p}<$ 0.05 belirlendi. Sayım tipi değişkenler açısından tek değişkenli analizlerde ki-kare testi kullanıldı. CD4+ T lenfositi sayısının koruyucu antikor gelişimi için ayırt edici değerini belirlemek amacıyla alıcı işlem karakteristikleri, [receiver operating characteristic (ROC)] eğrisi yöntemi kullanıldı. İleri analizler için antikor düzeyi açısından katılımcılar yeterli ve yeterli değil şeklinde iki gruba ayrıldı ve bunun cinsiyet, yaş ve tetanos aşılanma öyküsüne göre çok değişkenli analizi, lojistik regresyon ile yapıldı. Yaş değişkeni modele sürekli değişken olarak alındı.

\section{BULGULAR}

Çalışmaya HIV ile yaşayan 146 birey alınmıştır. Katılımcıların 126'sı erkek, 40’ı kadın olarak saptanmıştır. Yaş ortalaması $39.5 \pm 11.20$ yıl olarak tespit edilmiştir (Yaş aralığı= 18-69). Antikor testinin yapıldığı tarihlerde katılımcıların tümünün antiretroviral tedavi aldığı ve hepsinin viral yüklerinin saptanabilir seviyenin altında olduğu tespit edilmiştir. 


\begin{tabular}{|c|c|c|}
\hline & n (\%) & Toplam sayı \\
\hline Erkek & $126(86.3)$ & 146 \\
\hline Yaş, (ort $\left.{ }^{a} \pm S s^{b}\right)$ (en küçük-en büyük) yıl & $39.5 \pm 11.2(18-69)$ & 146 \\
\hline HIV enfeksiyonu süresi (ort \pm Ss) (en küçük-en büyük) yıl & $4.6 \pm 4.3(1-26)$ & 146 \\
\hline Tanı anında AIDS tanımlayan hastalık ${ }^{\mathrm{c}}$ & $10(6.8)$ & 146 \\
\hline Aşı anında CD4+ T lenfositi sayısı $<200$ hücre $/ \mathrm{mm}^{3}$ & $14(12)$ & 117 \\
\hline HIV enfeksiyonu tanısı almadan önce aşılananlar & $29(27.1)$ & 107 \\
\hline HIV tanısı aldıkları yıl içinde aşılananlar & $36(39.3)$ & 107 \\
\hline HIV tanısının ardından en az bir yıl sonra aşılananlar & $42(28.8)$ & 107 \\
\hline
\end{tabular}

Çalışmaya katılan HIV ile yaşayan bireylerin tamamı çocukluk çağındaki aşılama şemasının tamamladığını beyan etmiştir. Erişkin Aşı Polikliniği defterlerinden 107 (\%73.2) hastanın rapel doz tetanos aşısı yapılan tarih bilgisine ulaşılmıştır. Bu hastaların aşı olma zamanına en yakın CD4+ T lenfositi sayısı ortalama $485 \pm 279.18$ (1-1331) hücre/mm bulunmuştur. Hastaların yaklaşık üçte biri HIV enfeksiyonu tanısı almadan ortalama 2.6 yıl (2-6) önce, üçte biri tanı aldıkları yıl içinde ve üçte biri ise tanı aldıktan ortalama 5.6 yıl (1-24) sonra aşılanmıştır. Katılımcıların demografik özellikleri ve aşılanma bilgileri Tablo I'de sunulmuştur.

Toplam 146 katılımcının 114 (\%78.1)'ünün tetanos için koruyucu antikor düzeyine $(\geq 0.50 \mathrm{U} / \mathrm{ml})$ sahip olduğu saptanmıştır. Sadece 8 (\%0.05) katılımcıda antikor seviyesi 10 yıl koruyucu olacak düzeyde saptanmıştır. Aşılama bilgilerine ulaşılan 107 hastanın antikor düzeyleri tüm katılımcılarla benzer düzeyde bulunmuştur (Tablo II).

Tek değişkenli analizde, tetanos koruyucu antikor düzeyi ile cinsiyet, yaş (50 yaş sınır değer alınarak), tanı anında AIDS tanımlayan hastalık olup olmaması ve aşılama sırasındaki CD4+ T lenfositi sayısı arasındaki ilişki değerlendirilmiştir. Amerikan Hastalık Kontrol ve Önleme Merkezi [Centers for Disease Control and Prevention (CDC)] klinik evrelemesinde ${ }^{14}$ AIDS tanımlayan, CD4+ T lenfositi sayısı $\leq 200$ hücre $/ \mathrm{mm}^{3}$ olan ve ROC eğrisi

\begin{tabular}{lc}
\hline Tablo II. Aşılanma Bilgilerine Ulaşılan 107 Katılımcının Tetanos Antikoru Düzeyleri & \\
\hline Antikor düzeyi & $\mathbf{n}(\%)$ \\
\hline$<0.1 \mathrm{IU} / \mathrm{ml}$ (koruyuculuk yok, hemen rapel doz önerilir) & 0 \\
$0.1-0.5 \mathrm{IU} / \mathrm{ml}$ (zayıf koruyuculuk, uzun süreli koruyuculuk için rapel doz önerilir) & $22(20.5)$ \\
$>0.5-1 \mathrm{IU} / \mathrm{ml}$ (yeterli koruyuculuk, 2-5 yıl içinde rapel doz önerilir) & $26(24.2)$ \\
$>1.1-5.0 \mathrm{IU} / \mathrm{ml}$ (yeterli koruyuculuk, 5-10 yıl içinde rapel doz önerilir) & $53(49.6)$ \\
$>5.0 \mathrm{IU} / \mathrm{ml}$ (yeterli koruyuculuk 10 yıldan sonra rapel doz önerilir) & $6(5.7)$ \\
Toplam & 107
\end{tabular}


yönteminde koruyucu antikor seviyesi için en ideal CD4+ T lenfositi sayısı olarak saptanan $\geq 218$ hücre/mm $\mathrm{mm}^{3}$ için iki farklı sınır değer analize alınmıştır. Koruyucu antikor düzeyi saptanma olasılığı ise < 50 yaşında olanlarda dokuz kat (3.75-22.47), tanı anında AIDS tanımlayan hastalığı olmayanlarda dört kat (\%95 GA=1.24-13.93) ve aşı anında CD4+ T lenfositi sayısı $\geq 218 / \mathrm{mm}^{3}$ olanlarda beş kat yüksek (\%95 GA= 1.68-15.12) saptanmıştır (Tablo III).

Çok değişkenli analizde de aynı bağımsız değişkenler ile tetanos koruyucu antikor düzeyi saptanma olasılığı ilişkili bulunmuştur. Tablo III'te tek değişkenli ve çok değişkenli analiz sonuçları, olasılıklar oranı (OR) ve güven aralıkları verilmiştir.

HIV enfeksiyonu tanısından önce, tanı yılında ya da tanıdan sonra tetanos aşısı olanların ortanca antikor düzeyleri benzer bulunmuştur $(p=0.12)$. Aşılama tarihi bilinen 107 hastaya antikor düzeylerine göre yapılan rapel doz önerileri Tablo IV'te verilmiştir. Otuz iki (\%21.9) katılımcıya hemen, 37 (\%25.3)'sine beş yıl içinde, 69 (\%47.3)'una 10 yıl içinde, sekiz (\%5.5)'ine de 10 yıl sonra rapel doz önerilmiştir. On yılın üzerinde koruyucu antikor titresi (> $5.01 \mathrm{IU} / \mathrm{ml}$ ), aşılanma zamanından bağımsız olarak altı (\%5.6) kişide saptanmıştır. Aşılama zamanı ile antikor düzeyleri arasında korelasyon saptanmamıştır.

Tablo III. Demografik Özelliklere Göre Koruyucu Tetanos Antikoru Düzeyi, Tek Değişkenli ve Çok Değişkenli Analiz Sonuçları

\begin{tabular}{|c|c|c|c|c|}
\hline & $\begin{array}{c}\text { Koruyucu antikor } \\
\text { düzeyi olanlar } \\
n=114,(\%)\end{array}$ & $p^{a}$ & $\begin{array}{l}\text { Tek değişkenli } \\
\text { analiz OR } \\
\left(\% 95 \mathrm{GA}^{\mathrm{d}}\right)\end{array}$ & $\begin{array}{l}\text { Çok değişkenli } \\
\text { analiz OR } \\
\text { (\%95 GA) }\end{array}$ \\
\hline \multicolumn{5}{|l|}{ Cinsiyet } \\
\hline Erkek & $100(79.4)$ & 0.38 & $1.6(0.57-4.7)$ & - \\
\hline Kadın & $14(70)$ & & & \\
\hline \multicolumn{5}{|l|}{ Yaş } \\
\hline$<50$ yaş & $100(87.7)$ & 0.01 & $9.1(3.75-22.47)$ & $16.4(4.92-55.22)$ \\
\hline$\geq 50$ yaş & $14(43.8)$ & & & \\
\hline \multicolumn{5}{|l|}{$\begin{array}{l}\text { Tanı anında AIDS } \\
\text { tanımlayan hastalık }\end{array}$} \\
\hline Yok & $108(80.6)$ & 0.02 & $4.1(1.24-13.93)$ & $6.75(1.13-40.42)$ \\
\hline Var & $6(50)$ & & & \\
\hline \multicolumn{5}{|c|}{$\begin{array}{l}\text { Assılanma sırasında CD4+ T } \\
\text { lenfositi sayısı }\end{array}$} \\
\hline$\geq 200$ hücre $/ \mathrm{mm}^{3}$ & $85(82.5)$ & 0.14 & & \\
\hline$<200$ hücre $/ \mathrm{mm}^{3}$ & $9(64.3)$ & & & \\
\hline$\geq 218$ hücre $/ \mathrm{mm}^{3}$ & $85(85)$ & 0.05 & $5(1.68-15.12)$ & $4.2(1.05-17.44)$ \\
\hline$<218$ hücre $/ \mathrm{mm}^{3}$ & $9(52.9)$ & & & \\
\hline
\end{tabular}




\begin{tabular}{|c|c|c|c|c|c|}
\hline $\begin{array}{l}\text { Aşılanma } \\
\text { süresi }\end{array}$ & $\begin{array}{c}\text { Hemen rapel } \\
\text { doz } \\
(0.1-0.5 \mathrm{lU} / \mathrm{ml}) \\
\mathrm{a}, \mathrm{n}(\%)^{\mathrm{b}}\end{array}$ & $\begin{array}{c}2-5 \text { yıl içinde } \\
\text { rapel doz } \\
(>0.5-1.1 \mathrm{IU} / \\
\mathrm{ml}), \mathrm{n}(\%)\end{array}$ & $\begin{array}{c}5-10 \text { yıl içinde } \\
\text { rapel doz } \\
(>1.1-5.0 \mathrm{IU} / \\
\mathrm{ml}), \mathrm{n}(\%)\end{array}$ & $\begin{array}{c}10 \text { yıl sonra } \\
\text { rapel doz } \\
(>5.0 \mathrm{lU} / \mathrm{ml}) \\
\mathrm{n}(\%)\end{array}$ & Toplam \\
\hline $0-12$ ay & $2(8.9)$ & $6(26)$ & $14(60.8)$ & $1(4.3)$ & 23 \\
\hline 13- 48 ay & $17(28.8)$ & $14(60.8)$ & $26(44.1)$ & $2(3.4)$ & 59 \\
\hline $49-60$ ay & $0(0)$ & $2(18.1)$ & 9 (81.8) & $0(0)$ & 11 \\
\hline$>60$ ay & $3(21.4)$ & $2(14.2)$ & $6(42.8)$ & $3(21.4)$ & 14 \\
\hline Toplam & $22(20.5)$ & $24(22.4)$ & $54(50.4)$ & $6(5.6)$ & 107 \\
\hline
\end{tabular}

\section{TARTIŞMA}

Tetanos aşı ile önlenebilir bir hastalık olmasına rağmen, hala ülkemizde ve dünyada ölüm nedeni olmaya devam etmektedir ${ }^{15,16}$. Ülkemizde çocukluk çağında aşılanma oranları yüksek olsa da, erişkinlerde rapel dozlar genellikle bireyin kendi kararına bırakıldığından, aşılanma oranlarının düştüğü bilinmektedir ${ }^{2-6}$. Ülkemizde erişkinlerde tetanos antikoru seviyelerine bakılan bir çalışmada, erişkinlerin \%69'unda tetanosa karşı koruyucu antikor bulunmadığı ve aşı endikasyonu olduğu belirtilmiştir².

Erişkinler arasında HIV ile yaşayan bireyler özellikle aşı ile önlenebilir hastalıklar açısından riskli durumda olup, aşı yanıtları bağışıklığın baskılanmış olması nedeniyle daha düşük düzeyde olabilmektedir ${ }^{10-13}$. Ancak günümüzde etkili antiretroviral tedavi ile bağışıkı ğın daha hızlı düzeldiği ve aşı yanıtlarının buna paralel biçimde arttığı görülmüştür ${ }^{17,18}$. Güncel HIV tanı ve tedavi rehberlerinde, tetanos aşılaması için HIV negatif erişkinlerde olduğu gibi, CD4+ T lenfositi sayısından ve viral yükten bağımsız olarak primer aşı şeması ve bunun ardından 10 yılda bir rapel doz önerilmektedir ${ }^{19,20}$. Ancak gelişmiş ülkelerde dahi HIV ile yaşayan bireylerin aşılanma oranlarının yeterli düzeyde olmadığı bildirilmiştir. Amerika Birleşik Devletleri'nde 2006-2007 yılları arasında 20 merkezden toplam 326 HIV ile yaşayan çocuk ve ergenin (11-24 yaş, \%57'si kadın, \%54.9'u siyah ırktan) tıbbi kayıtları değerlendirildiğinde Tdap $\geq 1$ doz aşılama oranı oldukça düşük (\%28) saptanmıştır ${ }^{21}$. Ülkemizde HIV ile yaşayan bireylerin aşılanma oranları bilinmemektedir.

Çalışmamızda, HIV ile yaşayan ve farklı zaman dilimlerinde aşılanmış bireylerde tetanos antikorları araştırılmış ve koruyucu antikor düzeyiyle ilgili olabilecek etkenler değerlendirilmiştir. Fransa'da yapılan benzer bir çalışmada, bu ülkede yaşayan Sahra Altı Afrikalı 250 (151'i kadın, 99'u erkek) HIV ile yaşayan bireyin, ülkelerine seyahat öncesinde aşı ile önlenebilen hastalıklara karşı antikor düzeyleri değerlendirilmiştir ${ }^{22}$. Katılımcıların yaş ortalamasının 45 yıl, CD4+ T lenfositi sayılarının ortalamasının 440 hücre/ml ve \%95'nin viral yükünün saptanabilir seviyenin altında olduğu belirtilmiştir. Tetanos için koruyucu antikor düzeyi \%70.7 olarak saptanmıştır. Hastaların \%50'si daha önce tetanosa karşı aşılandığını belirtmiştir. Koruyucu antikor düzeyi ile aşılanma öyküsü ve cinsiyeti kadın olanlar arasında anlamlı bir ilişki saptanmıştır. Kadınlarda aşılanma öyküsü, daha genç 
yaşta olması, antiretroviral tedaviye (ART) daha yakın zamanda başlanması, HIV tanısının daha yakın zamanda konulması, daha yüksek eğitim seviyesinin koruyucu antikor seviyesi ile ilişkili olduğu bulunmuştur. Erkek hastalarda ise değerlendirilen değişkenlerden hiçbiri koruyucu antikor seviyesi ilişkili saptanmamıştır ${ }^{22}$. Avusturya'dan yapılan başka bir çalışmada da yaş ortalaması 45 yıl, \%77'si erkek, ortalama CD4+ T lenfositi sayısı $603 \pm$ 283 hücre/mm³ $\% 74$ 'ünde viral yük saptanabilir seviyenin altında olan 700 HIV ile yaşayan bireyde tetanos için koruyucu antikor düzeyi \%51 saptanmıştır ${ }^{23}$. Katılımcıların üçte birinin gelir düzeyi düşük ülkelerden gelen göçmenler olduğu bildirilmiştir. Koruyucu antikoru olan ve olmayan bireyler arasında bireyler arasında, cinsiyet, CD4+ T lenfositi sayısı, HIV enfeksiyonunun ve ART'nin süresi açısından fark saptanmamıştır. Tetanos IgG seronegatifliği Doğu Avrupa, Orta Asya, Güney Asya ve Afrika'dan gelen göçmenlerde daha sık görülmüştür $(O R=0.39, \% 95 \mathrm{GA}=0.28-0.53, \mathrm{p}<0.001)$. Çalışmamızda ise koruyucu antikor düzeyi \%78.1 olarak saptanmıştır. Yaşın $<50$ yıl olması, tanı anında AIDS'i tanımlayan hastalığın olmaması ve aşı anında CD4+ T lenfositi sayısının $\geq 218$ hücre/ $\mathrm{mm}^{3}$ olması koruyucu antikor düzeyi ile ilişkili saptanmıştır. Farklı ülkelerde farklı aşılama şemalarının bulunması nedeniyle farklı seropozitiflik düzeyleri görülmekte, çalışmalarda seropozitifliğe etki eden faktörler katılımcı grubunun özelliklerine göre değişmektedir. Çalışmamızda daha yüksek seropozitiflik saptanmasının nedeni ülkemizde çocukluk aşılama şemasının üç dozdan fazla olması, aşılamanın yaygın olarak uygulanması, askerlik sırasında ve gebelikte rapel dozların yapılması olabilir.

Aşı, bu ölümcül hastalıktan korunmanın en önemli yoludur. Ülkemizde, genel toplumda tetanos koruyucu antikor titreleri, çalışmanın yapıldığı bölgelere göre yetişkinlerde \%39.3-84.4 arasındadır $^{2-6}$. Hem ülkemizde hem de diğer ülkelerde yapılan çalışmalarda, antikor seviyelerinin yaş ilerledikçe belirgin ölçüde düştüğü görülmüştür ${ }^{24-27}$. Ülkemizden yakın zamanda yapılan bir çalışmada, koruyucu düzeyde antikor 30-40 yaş grubunun \%70'inde saptanırken, 51-60 yaş grubunda \%31'e inmektedir ${ }^{6}$. Çalışmamızda da hem tek değişkenli hem de çok değişkenli analizde, 50 yaşın altındaki bireylerde koruyucu antikor düzeyinin daha fazla olduğu saptanmıştır.

Tetanos aşısı toksoid aşı olduğundan, CD4+ T lenfositi düzeyi düşük olan hastalarda da güvenle kullanılabilmektedir. Çalışmamızda, aşı anında CD4+ T lenfositi sayısı düşük olanlarda antikor titresinin daha düşük olduğu tespit edilmiştir. Toksoid aşıları daha çok TH2 hücreleri üzerinden antikor yanıtı oluşturduğundan, aşı etkinliğinin CD4+ T hücre sayısı ile bağlantılı olması beklenen bir sonuçtur. Araştırmamızda, CD4+ T lenfositi sayısının > 218 hücre/mm³ olmasının koruyucu antikor düzeyi saptanma olasılığını dört kat arttırdığı saptanmıştır. Bu konuda, farklı çalışmalarda CD4+ T lenfositi sayısının aşı sonrası antikor yanıtıyla ilişkili olduğu bildirilmiştir ${ }^{11,21,26}$. Aşılama sırasında CD4+ T lenfositi düzeyi düşük olan HIV ile yaşayan bireylerde, aşılamadan sonra antikor titresi bakılması ve gereken kişilere rapel doz yapılması uygun olabilir.

Ülkemizde, geç dönemde HIV enfeksiyonu tanısı alma oranı \%50'nin üzerindedir. Hastaların önemli bir kısmı AIDS'i tanımlayan hastalıklar, endikatör hastalıklar veya diğer cinsel yolla bulaşan hastalıklar nedeniyle test yapılması sonucunda tanı almaktadır ${ }^{27,28}$. Ça- 
lışmamızda da katılımcıların \%6.8'inde tanı anında AIDS tanımlayıcı hastalık bulunduğu ve koruyucu antikor düzeyinin aşı anındaki CD4+ T lenfositi sayısından bağımsız olarak bu grupta düşük olduğu tespit edilmiştir. Aşılama anında AIDS aşamasında olmayan, ancak geçmişte AIDS aşamasına gelmiş kişilerde de aşıya karşı yanıtın düşük olduğu bildirilmiştir $^{11,27}$. Bunun nedeni, CD4+ T lenfositi sayısı yükselse bile, bağışık yanıtın fonksiyonel olarak daha geç normale dönmesi, hatta bazı immünolojik işlevlerin geri dönüşü olmayan bir biçimde bozulması olabilir. Çalışmamızda bağışık yanıt ile ilgili olabilecek, HIV enfeksiyonunun süresi ve tanıdan önce ya da sonra aşılanma ile antikor düzeyleri arasında anlamlı bir ilişki saptanmamıştır.

Her ne kadar HIV ile enfekte bireylerde tetanos aşılama önerileri genel toplum için yapılanlara benzer olsa da, çalışmada, rutin aşılama şemasına göre aşılandıkları bilinen HIV ile yaşayan bireylerde, tetanosdan en az 10 yll boyunca koruyacak düzeyde antikor bulunanların oranının son derece düşük (\%5.6) olduğu tespit edilmiştir. Çeşitli yayınlarda, HIV ile enfekte yetişkin erkeklerde ${ }^{10,11}$, kadınlarda $^{13}$, ergenlerde ${ }^{12}$ ve çocuklarda ${ }^{29,30}$ tetanos toksoid aşısına verilen immünolojik cevabın kontrol grubundakine göre daha az olduğu gösterilmiştir. Çalışmamızda, antikor testinden önceki beş yıl içinde aşılananlarda dahi 10 yıllık koruyucu antikor titresine sahip kişilerin sayısının çok az olduğu görülmüştür. Bu bulguların ışı̆̆ı altında, HIV ile yaşayan bireylerde, rapel dozların 10 yıldan daha kısa zamanda uygulanması konusu daha ayrıntıı araştırılmalı ve değerlendirilmelidir.

Antikor titresi bakılan tüm hastaların aşılanma zamanına ulaşılmamış olması çalışmamızın kısıtııı̆ı̆ıır. Bu durum, ülkemizde erişkin aşı karnesi uygulamasının olmaması ve yapılan aşıların e-nabız gibi sistemlere girilmemiş olmasından kaynaklanmaktadır.

Sonuç olarak, HIV ile enfekte bireylerde tetanos antikoru yanıtının genel toplumdakinden daha az olabileceği göz önünde bulundurulmalı ve özellikle aşılama anındaki CD4+ T lenfositi sayısı < 200 hücre $/ \mathrm{mm}^{3}$ olan, 50 yaşın üzerindeki ve tanı anında AIDS'i tanımlayan hastalığı olan kişiler, rapel dozun daha erken yapılması açısından değerlendirilmelidir.

\section{ETIK KURUL ONAYI}

Bu çalışma, Ege Üniversitesi Rektörlüğü Tıp Fakültesi Dekanlığı Tıbbi Araştırmalar Etik Kurulu onayı ile gerçekleştirildi (Tarih: 29.01.2021 ve Karar No: 21-1.IT/67).

\section{ÇIKAR ÇATIŞMASI}

Yazarlar bu makale ile ilgili herhangi bir çıkar çatışması bildirmemişlerdir.

\section{KAYNAKLAR}

1. Nayir T, Nazlıcan E, Şahin M, Kara F, Alp Meşe E. Effects of immunization program on morbidity and mortality rates of vaccine-preventable diseases in Turkey. Turk J Med Sci 2020; 50(8): 1909-15.

2. Tanriover MD, Soyler C, Ascioglu S, Cankurtaran M, Unal S. Low seroprevalence of diphtheria, tetanus and pertussis in ambulatory adult patients: the need for lifelong vaccination. Eur J Intern Med 2014; 25(6): 52832.

3. Kader Ç, Balci M, Erbay A. Evaluation of tetanus antibody levels in adults in Yozgat, Turkey. Turk J Med Sci 2016; 46(3): 646-50. 
4. Tasbakan M, Durusoy R, Tosun S, Akyol D, Pullukçu H, Yamazhan T. Relationship between tetanus antitoxin titration level and vaccination history. J Clin Exp Invest 2017; (8)4: 104-9.

5. Sahan S, Demirbilek Y, Sonmez C, Temel F, Sencan I. Epidemiological study of tetanus seropositivity levels in different age groups in Ankara province, Turkey, 2017. Jpn J Infect Dis 2019; 72(1): 14-8.

6. Alkan I, Ozturk CE, Calıskan E, Akar N. Investigation of tetanus antibody levels in adults. Duzce Med J 2019; 21(2): 98-102.

7. T.C. Sağlık Bakanlığı. Aşı Rehberi. Risk grubu aşılamaları konulu ve 21001706 sayılı genelge. Available from: https://asirehberi.saglik.gov.tr/genelgeler/risk-grubu-genelgesi. (Accessed date: 23 Apr 2021).

8. T.C. Sağıık Bakanlığı Halk Sağlığı Genel Müdürlüğü. Aşı Portalı. Available from: https://asi.saglik.gov.tr/asikimlere-yapilir/liste/30-yeti\%C5\%9Fkin-a\%C5\%9F\%C4\%B1lama.html (Accessed date: 23 Apr 2021).

9. Enfeksiyon Hastalıkları ve Klinik Mikrobiyoloji Uzmanlık Derneği (EKMUD). Erişkin Aşılama Rehberi 2019 Available from: https://www.ekmud.org.tr/haber/264-turkiye-ekmud-eriskin-bagisiklama-rehberi (Accessed date: 23 Apr 2021).

10. Dieye TN, Sow PS, Simonart T, Guèye-Ndiaye A, Popper SJ, Delforge ML, et al. Immunologic and virologic response after tetanus toxoid booster among HIV-1- and HIV-2-infected Senegalese individuals. Vaccine 2001; 20(5-6): 905-13.

11. Kroon FP, van Dissel JT, de Jong JC, van Furth R. Antibody response to influenza, tetanus and pneumococcal vaccines in HIV-seropositive individuals in relation to the number of CD4 T lymphocytes. AIDS 1994; 8(4): 469-76.

12. Spina FG, Gouvea A, Succi RCM, Calanca F, Weckx LY, Terreri MT, et al. Immune response to a Tdap booster in vertically HIV-infected adolescents. Vaccine 2018; 36(37): 5609-16.

13. Bonetti TC, Succi RC, Weckx LY, Tavares-Lopes L, de Moraes-Pinto MI. Tetanus and diphtheria antibodies and response to a booster dose in Brazilian HIV-1-infected women. Vaccine 2004; 22(27-28): 3707-12.

14. Centers for Disease Control and Prevention. Revised surveillance case definition for HIV infection. MMWR Recomm Rep 2014; 63(RR03): 1-10.

15. Tosun S, Batirel A, Oluk Al, Aksoy F, Puca E, Bénézit F, et al. Tetanus in adults: results of the multicenter ID-IRI study. Eur J Clin Microbiol Infect Dis 2017; 36(8): 1455-62.

16. Sako FB, Sylla AO, Diallo MOS, Touré A, Traoré FA, Tounkara TM, et al. Tetanus: epidemiology and factors associated with death in the department of tropical and infectious diseases of Donka National Hospital, Guinea. Med Sante Trop 2019; 29(3): 333-6.

17. Burton CT, Goodall RL, Samri A, Autran B, Kelleher AD, Poli G, et al. INITIO Trial International Co-ordinating Committee. Restoration of anti-tetanus toxoid responses in patients initiating highly active antiretroviral therapy with or without a boost immunization: an INITIO substudy. Clin Exp Immunol 2008; 152(2): 252-7.

18. Andrade RM, Andrade AF, Lazaro MA, Vieira MM, Barros PO, Borner AR, et al. Failure of highly active antiretroviral therapy in reconstituting immune response to Clostridium tetani vaccine in aged AIDS patients. J Acquir Immune Defic Syndr 2010; 54(1): 10-7.

19. European AIDS Clinical Society (EACS) Guidelines Version 11.0 Available from: https://www.eacsociety.org/ media/final2021 eacsguidelinesv11.0_oct2021.pdf (Accessed date: Oct 2021).

20. Türk HIV/AIDS Platformu. HIV/AIDS Tanı, İzlem ve Tedavi El Kitabı, sürüm: 1.0.

21. Setse RW, Siberry GK, Moss WJ, Wheeling J, Bohannon BA, Dominguez KL, et al. Meningococcal conjugate and tetanus toxoid, reduced diphtheria toxoid and acellular pertussis vaccination among HIV-infected youth. Pediatr Infect Dis J 2016; 35(5): e152-7.

22. Mullaert J, Abgrall S, Lele N, Batteux F, Slama LB, Meritet JF, et al. Diphtheria, tetanus, poliomyelitis, yellow fever and hepatitis B seroprevalence among HIV1-infected migrants. Results from the ANRS VIHVO vaccine sub-study. Vaccine 2015; 33(38): 4938-44.

23. Grabmeier-Pfistershammer K, Herkner H, Touzeau-Roemer V, Rieger A, Burgmann H, Poeppl W. Low tetanus, diphtheria and acellular pertussis (Tdap) vaccination coverage among HIV infected individuals in Austria. Vaccine 2015; 33(32): 3929-32. 
24. Gidding HF, Bachouse JL, Burgess MA, Gilbert GL. Immunity to diphtheria and tetanus in Australia: a national serosurvey. Med J Aust 2005; 183(6): 301-4.

25. Rapisarda V, Bracci M, Nunnari G, Ferrante M, Ledda C. Tetanus immunity in construction workers in Italy. Occup Med (Lond) 2014; 64(3): 217-9.

26. Ang LW, James L, Goh KT. Prevalence of diphtheria and tetanus antibodies among adults in Singapore: a national serological study to identify most susceptible population groups. J Public Health (Oxf) 2016; 38(1): 99-105.

27. Janoff EN, Hardy WD, Smith PD, Wahl SM. Humoral recall responses in HIV infection. Levels, specificity, and affinity of antigen-specific IgG. J Immunol 1991; 147(7): 2130-5.

28. Erdinc FS, Dokuzoguz B, Unal S, Komur S, Inkaya AC, Inan D, et al.Temporal trends in the epidemiology of HIV in Turkey. Curr HIV Res 2020; 18(4): 258-66.

29. Korkusuz R, Şenoğlu S. Syphilis seroprevalence and associated risk factors in HIV-infected individuals. Mediterr J Infect Microb Antimicrob 2020; 9: 13.

30. Choudhury SA, Matin F. Subnormal and waning immunity to tetanus toxoid in previously vaccinated HIVinfected children and response to booster doses of the vaccine. Int J Infect Dis 2013; 17(12): e1249-51.

31. Succi RCM, Krauss MR, Harris DR, Machado DM, de Moraes-Pinto MI, Mussi-Pinhata MM, et al. Immunity after childhood vaccinations in perinatally HIV-exposed children with and without HIV Infection in Latin America. Pediatr Infect Dis J 2018; 37(4): 304-09. 